\title{
Introduction \& Appendix: Latin America in the Time of the Coronavirus
}

Francisco Carballo and Inna Pravdenko

\section{(2) OpenEdition \\ Journals}

Electronic version

URL: http://journals.openedition.org/transtexts/1346

DOI: $10.4000 /$ transtexts.1346

ISSN: 2105-2549

Publisher

Gregory B. Lee

Electronic reference

Francisco Carballo and Inna Pravdenko, «Introduction \& Appendix: Latin America in the Time of the Coronavirus », Transtext(e)s Transcultures 跨文本跨文化 [Online], 14 | 2019, Online since 31 December 2019, connection on 28 July 2020. URL : http://journals.openedition.org/transtexts/1346 ; DOI : https://doi.org/10.4000/transtexts. 1346

This text was automatically generated on 28 July 2020

(c) Tous droits réservés 


\title{
Introduction \& Appendix: Latin America in the Time of the Coronavirus
}

\author{
Francisco Carballo and Inna Pravdenko
}

1 This special issue of Transtext(e)s Trancultures 跨文本跨文化 is the culmination of several months of intense editorial work. With this selection of essays, we intend to map out some of the current themes explored by the scholars who use Latin America as their research archive. It is hardly a coincidence that this issue appears in a European journal aiming at imagining novel explanations and representations of the world. The articles below seek to reconceive different aspects of the Latin American experience: political, economic, cultural and historiographical premises are at stake in these pages.

2 Latin America has been overturned in the last few years. In 2020, the political, economic and cultural environment is less hopeful than twenty years ago, at the turn of the century. The pink tide that relaunched left-leaning politics is in retreat. In some places, it lies in disgrace; in others, it struggles to resist the onslaughts of its enemies, and more often than not, it suffers from the rapacity of its leaders. The 2008 economic meltdown that started in Western metropolises slowly but surely made its way into Latin America. In the wake of the financial crisis neoliberalism made a comeback, and yet neoclassical policies lost the scientific legitimacy they once enjoyed. For the second time, neoliberalism's poster boys are not technocrats with distinguished academic credentials but internet trolls. Extractivism reigns on the continent as the surest way of producing revenue in foreign currencies, whereas its tragic side effects, causing social and environmental devastation on a colossal scale, for the most part go unnoticed. The extractivist dogma once again illuminates an age-old curse: the inability of Latin American countries to escape their role as producers of raw materials, always at the mercy of the fluctuating global market. As its inevitable corollary, the economies grow on paper, but their benefits are still beyond the reach of the majority of the population. 
3 Meanwhile, civil violence is running amok on the vast Latin American territory, from the northern border of Mexico to the megacities of the Southern Cone. In certain places, the mafia challenges the state's monopoly over violence, and endemic corruption undermines citizens' trust in democracy. ${ }^{1}$ Judicial coups d'état, soft dictatorships, digital civil wars, and the violation of human rights, sometimes outsourced by governments to more nefarious criminal actors, define the contemporary political landscape. Authoritarianism is rising on the horizon, but this time, without any democratic façades or hiding in the shadows. It proudly vindicates the criminal legacy of the Latin American dictatorships of the twentieth century and is as militant as the most radical of its adversaries. This is authoritarianism that unlike left-wing populism is decidedly undemocratic. ${ }^{2}$

4 In Brazil, Jair Bolsonaro seems to be less interested in the meticulous routines of policymaking than in proselytising an outlandish brand of conservative politics, one that invites comparisons with classical fascism. El Salvador's President Nayib Bukele is proving a loyal follower of Carl Schmitt, whose famous dictum, "Sovereign is he who decides on the exception," he takes at face value. Bukele and some of his counterparts in the region thrive on creating and managing crisis. The state of exception allows them to dispense, for example, with the most crucial of public demands: government accountability. The Bolivian opposition that ousted Evo Morales from the presidency is galvanised around a vociferous brand of Christian fundamentalism. Its two most extreme leaders, Chi Hyun Chung and Luis Fernando Camacho, made the Bible an antithesis to the 2009 Constitution, the law that declared Bolivia a secular and plurinational state. Assuming office after Morales, Jeanine Añez said in her inauguration speech: "God has allowed the Bible to enter the Palace again. May He bless us." 3

5 Caught up in the state of radical polarisation, the region is steadily edging towards a breaking point. The cry for solutions to longstanding problems is reaching the level of exasperation, and the seduction of easy fixes is becoming more difficult to resist. Populism, a well-known phenomenon in Latin America, is changing ideological skin, moving from the left to the right. However, a closer look reveals these categories as a little hollow. What exactly are the differences between one side and the other? Programmatically speaking, they embrace comparable platitudes: the end of poverty, a robust economic growth, the building up of the national infrastructure and a guarantee of justice for everyone - in short, they suggest grabbing once and for all the slippery promises of development. No doubt the preferred route to economic and social progress varies among ideological rivals, but there are extraordinary similarities in some of the most recurrent recipes.

6 In the next decade, most Latin American countries will be commemorating two hundred years of independence. Both sides of the ideological divide hold tight to the last consensus, which goes unchallenged in the mainstream of political and social debates: modernisation against all the odds. The founding myth of the Latin American republics derives from the stale values of the nineteenth century: order and progress. There is also the third value; it is rarely mentioned in the public discussion, but there is hardly anyone unaware of its significance: racism. Racial discrimination is the last barrier that prevents the region from radical democratisation. Is it possible to reestablish these countries on different premises? Is it feasible to go beyond the idea of economic growth, the indiscriminate exploitation of natural resources, and the 
obsession with the peoples who are supposedly at the vanguard of modernity? Is it conceivable to defeat racism once and for all?

7 Overwhelmed by its challenges and contradictions, Latin America, nevertheless, remains a foster child of globalisation. The most recent coronavirus mutation, SARSCOV-2, is yet another proof of this deeply troubled relationship. It landed in the area on 26 February 2020, when Brazil confirmed its first case in São Paulo. The most powerful country in the region emerged at the forefront of the forces of globalisation in its sphere of influence. Argentine essayist Juan José Sebreli confessed his astonishment at such a universal phenomenon. ${ }^{4}$ The effects of the pandemic were felt at the same time in Paris and Buenos Aires; Rome and Rio de Janeiro; Berlin and Lima; New York and Mexico City; Beijing and Santiago de Chile. The tragedy brought the world together, locking it in the same historical-temporal space. Globalisation once again rushed into the Americas with the most powerful and persuasive of its weapons, a virus.

The first cases of the disease that gained notoriety in Latin America were reputable businessmen infected in remote and sophisticated places such as Cortina d'Ampezzo, the Salamanca district in Madrid, the French Concession in Shanghai, or some corporate building in the Gangnam area in Seoul. Miguel Barbosa, the Governor of the Mexican State of Puebla, ruled that the coronavirus was a disease of the rich, that it was nature's revenge, punishing the affluent for their excesses. He further prophesied that the poor would be immune to the new disease as the virus chose its victims by socioeconomic criteria. Soon Barbosa had to eat his words. The most socially vulnerable areas rapidly became the hotspots of the virus in Latin America: the favelas of Brazil, the villas of Buenos Aires' urban sprawl, the colonias populares of Mexico City. The pandemic also hit the most vulnerable regions of the Amazon. Entering through the gates of Amazonian cities (Manaus, Iquitos, Coca, Leticia, Belem), it spread into the indigenous communities that prudently tried to maintain distance from the national societies with whom they are forced to coexist. Then the virus invaded the overcrowded prisons of the region, in particular Colombia, Peru and El Salvador. It also targeted the refugee camps along the Mexico/US border, where thousands of Central Americans wait for an improbable asylum status from the Trump administration.

The first evidence of the magnitude of the problem came from Guayaquil. Snapshots taken with mobile phones showed bodies abandoned in the streets of the Ecuadorian port. The second example came from Mexico City: the government was giving out such flattering figures that people began to doubt their veracity. Soon it was discovered that the crematory ovens were working non-stop, and the bodies were piling up on the floors in morgues. There were not enough freezers to store the dead. As governments reluctantly decided to implement a general quarantine, a spectre familiar to Latin Americans appeared: hunger. In Guatemala and El Salvador, white flags marked the homes where both food and money had run out. In Peru, the unprecedented happened: the decades-long internal migration of people from the countryside to the outskirts of Lima, documented exceptionally well by Aníbal Quijano, reversed in just a few days. ${ }^{5}$ The coronavirus gave a U-turn to the phenomenon that lies at the very foundation of the social theory explaining the battered modernity of Latin America. Hundreds of people left the Peruvian capital to return to their places of origin. This (counter)exodus became deeply symbolic: the city could no longer feed its working poor. The repopulation of Peru was stopped by the security forces, who feared that the returnees would spread the virus across the national territory. 
10 By rough estimations, in 2020, Latin American economic activity will contract by 9.2 per cent. By the end of the year, Latin America's per capita GDP will reach 2010 levels. In just five months of the pandemic, the wealth accumulated over the past ten years has been lost. The regional economies will suffer from the standstill of the quarantine periods with their reduced activity; they will also suffer from their excessive dependence on the global market flows that keep them afloat. Suffice it to mention four possible scenarios: the fall in the prices of raw materials, the dwindling of international tourism, the decrease in foreign direct investment and the freeze on remittances sent by the continent's migrant workers. The governments have taken some measures to alleviate the ravages of the social and economic crises resulting from COVID-19. Argentina, Ecuador and Paraguay have implemented programmes of cash and food distribution to those in need. Chile, Colombia and Peru have followed European models by covering furloughed workers and providing preferential loans to medium and small enterprises. Brazil passed Law 13982, the "corona-voucher," which offered informal workers something resembling a universal basic income. The aid amounts to $€ 90$ per month for ninety days. These are significant gestures, and yet they are insufficient. Latin America has little room for the broad repertoire of monetary policies open in other latitudes. The coronavirus came at a time of maximum financial weakness, as evidenced by Argentina's debt default and the Mexican state's accelerated shrinkage due to the objective lack of resources.

11 Exposing the long-ignored evils of modernity, the pandemic has accidentally become a theoretical tool, calling for the rethinking of the old and new distortions of neoliberal policies, the promises of globalisation and of its cultural imperatives. Acknowledging the scale of the tragedy and its impact on the intellectual climate of today, we suggest thinking of it as a lens that magnifies the concerns expressed in this issue by turning them into pieces of the same puzzle. In a timely fashion, it makes room for the emotional response as a counterpart to the intellectual exercise within the context of an academic publication. Addressing different themes, travelling to various places and traversing temporalities, the authors unintentionally, but convincingly, construct a picture of a continent that keeps recycling some of its unresolved problems and at the same time strives to imagine other forms of being. This internal conflict is evident for scholars working on Latin America; they have a personal stake in their subjects and go beyond the demands of mainstream academic objectivity and impartiality. Nonetheless, all contributions to the issue are anchored in robust scholarship that does justice to the complexity of the topics they explore.

12 One of the common threads in this issue is the focus on the concept of the crisis. Although the contributors tackle different incarnations of this phenomenon, they all see crises not so much as problems to be solved, but as opportunities for substantive transformations. In an essay on the recent civil protests in Chile, Felipe Lagos-Rojas contemplates the idea of framing the crisis as a method. Using the work of René Zavaleta Mercado, Lagos-Rojas analyses the behaviour of the neoliberal government in the moment of exception as opposed to the state of "normality." He uncovers the fascist essence of the capitalist state that uses an array of repressive strategies to eliminate any possibility for new subjectivities to form and synchronise. The counterreaction to this government brutality is an emergence of "constitutive moments" that allow for the encounter and consolidation of otherwise separate social groups. The insurrectional process in Chile was suspended with the arrival of the coronavirus, but 
considering the common origins of the neoliberal and COVID crises it might push on to the next level.

The notion of the "normality" mentioned by Lagos-Rojas is elaborated in Rita Segato's "meditation." The normal is an elusive concept: it emerges as a counteraction to the anomalies that it itself creates and tries to destroy. European modernity conceptualises the normal as an instrument of self-determination and a device of oppression against the Other. The tension between the normal and the anomalous manifests itself in many aspects, from small automatisms of daily life to the foundations of international law. At this juncture, the need to overcome the pressure of normalisation (and its twin, universalisation) has become crucial. Touching upon the origins of modernity and the decline of the European imagination, Segato in sweeping brushstrokes introduces some fundamental concepts of decolonial thinking. Her essay embraces the contradictions and confusions of the day, yet grows from an impeccably sound theoretical base.

José Luis Paredes Pacho leads with the idea of "independence as inevitability" in the text on the magazine La PusModerna. This magazine was published over eight years, from 1989 to 1997. Instead of being a manifestation of a coherent aesthetic ideology, it was a confluence of different underground art forms, currents, and modes of cultural production. Its trajectory marked the critical transformation of the cultural landscape in Mexico under the influence of a tightening neoliberal grip on the arts. Pacho's article is a significant contribution to the Mexican intellectual history of the late twentieth century that poses essential questions regarding the status of the "counter-culture" and the "underground" in the societies dominated by market logic.

The article by Cielo Zaidenwerg and Melisa Pesoa presents the case of widening the field of historical investigation to avoid homogenising narratives. In their analysis of the publications issued in the National Territory of Río Negro at the turn of the twentieth century, the authors emphasise the contribution of the regional press to the nation-building process in Argentina. They underline the correlations between regional and national discourses, which give a more nuanced reading of the meta-narrative of Argentinisation. Such focus on the marginal phenomena in journalism and the press demonstrates their unrestricted potential for questioning historiographies of the twentieth-century.

16 Scrutiny of pre-conceived concepts is what distinguishes Katharina Richter's research. She relies on Latin American thinkers to point out the weak spots in the degrowth debate coming out of Europe. She deconstructs the ontological tenets behind the degrowth discourse to prove that it is still embedded in the exploitative logic of modernity. Richter's analysis targets the deep-laid foundations of both growth and degrowth paradigms. By framing her analysis as a "sympathetic critique," she, nevertheless, embraces the possibility of a dialogue and much-desired cooperation between the proponents of the conventional degrowth and the bearers of indigenous knowledge(s). Moreover, the author indicates the practical steps that could achieve such cooperation.

17 Francisco Carballo explores the crucial role of the notion of exclusion, and its semantic correlate, barbarism, in the conceptualisation of the Ancient Greek polis, the foundational political form in Western philosophy. The author observes how Niklas Luhmann updates many of the motives of classical exclusion in an attempt to grasp the social context of the Global South. According to Luhmann's systems theory, the Brazilian favelas represent a theoretical-methodological problem that questions 
simplistic accounts of Western modernity and its vacuous promises of universal inclusion. Nevertheless, when it becomes impossible to describe functional differentiation in places defying the social order inherent to contemporary modern societies, the slums of the Global South show the limits of Luhmann's theoretical building.

This issue explores the challenges caused and the possibilities opened by the recurring and newly-emerging crises from different standpoints and overlapping perspectives. Employing diverse theoretical bases, the authors suggest abolishing some of the imposed categories and knowledge production practices that have reigned for decades. For many reasons, this issue has become something different from what it was intended to be, but this is what we wanted to underline: the possibility of change in uncertain times.

\section{NOTES}

1. See, as an example, William Wheeler, State of War: MS-13 and El Salvador's World of Violence, New York, Columbia Global Reports, 2020.

2. Chantal Mouffe e Íñigo Errejón, "L'Amérique latine et les expériences national-populaires" in Construire un people. Pour une radicalisation de la démocratie, Paris, Les Éditions du Cerf, 2017.

3. “'La Biblia vuelve a entrar al Palacio': Jeanine Añez, presidenta interina de Bolivia," El País, 13 de noviembre de 2019, https://www.elpais.com.co/mundo/la-biblia-vuelve-a-entrar-a-palaciojeanine-anez-presidenta-interina-de-bolivia.html

4. Juan José Sebreli interviewed by Pablo Sirvén, "Hablemos de Otra Cosa," La Nación TV, 8 de mayo de 2020.

5. Aníbal Quijano, Dependencia, Urbanización y cambio social en Latinoamérica, Lima, Mosca Azul Editores, 1977; Aníbal Quijano, Dominación y cultura: lo cholo y el conflicto cultural en el Perú, Lima, Mosca Azul Editores, 1980.

\section{AUTHORS}

\section{FRANCISCO CARBALLO}

Francisco Carballo is Lecturer in the politics and cultures of Latin America at Goldsmiths, University of London. He co-directs the Centre for Postcolonial Studies there and serves on the editorial board of the journal Postcolonial Studies.

\section{INNA PRAVDENKO}

Inna Pravdenko holds a PhD in Transcultural Studies. She has published on Latin American artistic migration to Paris and the reception of French painting in Russia. Currently, she is 
developing a book project on the "alternative history" of the late nineteenth century painting from Latin American perspective. 